\title{
Aqueous extract of pequi fruit to control Spodoptera frugiperda in corn
}

\section{Extrato aquoso de fruto de pequizeiro para o controle de Spodoptera frugiperda em milho}

\author{
Maria das Dores da Cruz Souza ${ }^{1 *}$, Teresinha Augusta Giustolin', Clarice Diniz Alvarenga', \\ João Natal de Jesus Costa', Ignácio Aspiazú'
}

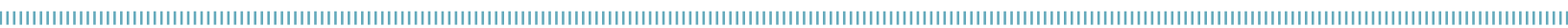

\begin{abstract}
Pequi fruit peels contain steroids, triterpenes, flavonoids, tannins, and saponins, compounds that are potentially useful for integrated pest management. As such, the aim of this study was to evaluate the insecticidal activity of aqueous extracts of pequi fruit peels on Spodoptera frugiperda. Field-grown corn plants of the cultivar 'Al Alvaré' were sprayed with extract concentrations of $0.8 \%, 2.5 \%, 5 \%$, and $10 \%(\mathrm{v} / \mathrm{v})$ 40 and 47 days after germination. The pequi peels were chopped, oven dried $\left(65^{\circ} \mathrm{C}\right.$ for 72 hours), and ground in a grinding mill. The resulting powder was used to prepare a base-line extract $(10 \%)$, and the other concentrations evaluated were prepared by diluting this extract. The intensity of the damage caused by S. frugiperda caterpillars was evaluated 43, 46, 50, and 53 days after germination, using a visual scoring scale. Application of the extract decreased the amount of damage caused by the caterpillars. The $5 \%$ extract concentration was the most effective, while the $10 \%$ extract concentration showed evidence of phytotoxicity after the second spraying. These results suggest that the pequi extract is toxic to the $S$. frugiperda caterpillars and can be used for the management of this pest.
\end{abstract}

KEYWORDS: Caryocar brasiliense, fall armyworm, botanical insecticide.
RESUMO: Nas cascas dos frutos de pequi já foram identificados esteroides, triterpenos, flavonoides, taninos e saponinas, substâncias promissoras no manejo integrado de pragas. Com base nesta informação, objetivou-se com este trabalho avaliar a ação inseticida de extratos aquosos das cascas dos frutos de pequi a Spodoptera frugiperda. O ensaio foi realizado em campo, utilizando sementes de milho do cultivar 'AL Alvaré' que aos 40 e 47 dias após a germinação foram pulverizadas com concentraçóes dos extratos de $0,8 \%$, $2,5 \%, 5 \%$ e $10 \%(\mathrm{v} / \mathrm{v})$. Os extratos foram preparados a partir de cascas dos frutos de pequi que, após picadas, foram secas em estufa $\left(65^{\circ} \mathrm{C}\right.$, por 72 horas) e moídas em moinho de facas. Com o pó foi preparado um extrato padrão $(10,0 \%)$. As demais concentraçôes foram obtidas a partir deste extrato. Foram avaliadas a intensidade das injúrias causadas pelas lagartas de $S$. frugiperda em plantas com 43, 46, 50 e 53 dias, utilizando uma escala visual de notas. As pulverizaçóes dos extratos reduziram o número de injúrias provocadas pelas lagartas. A concentração de $5 \%$ foi a mais eficiente nesta redução e a de $10 \%$ causou fitotoxicidade após a segunda pulverização. $\mathrm{O}$ extrato pequi é tóxico às lagartas de $S$. frugiperda e pode ser utilizado no manejo desta praga.

PALAVRAS-CHAVE: Caryocar brasiliense, lagarta do cartucho-do-milho, inseticida botânico . 
The northern region of Minas Gerais State, Brazil is an important producer and consumer of pequi fruit (Caryocar brasiliense Camb.). During processing, the peel is removed to access the commercially valuable interior, which generates an excessive amount of waste and in turn contaminates the environment. This waste could be avoided if a use for the peel was found. Interestingly, steroids, triterpenes, flavonoids, tannins, and saponins have been identified in the peels of pequi fruit (RESENDE et al., 2011). These compounds, which are secondary metabolites in the plants, are produced to act as a defense mechanism and have proved to be toxic to some pests (COITINHO et al., 2006a, b). The use of extracts from pequi fruit peels for controlling insects could be an interesting solution, since it would reduce waste and could be used in conjunction with other pest control methods. Thus, given the possibility of this practical use for pequi fruit peels, we evaluated the ability of an aqueous extract, delivered as a foliar spray, to limit damage to corn caused by fall armyworm (Spodoptera frugiperda).

The tests were performed in field conditions in the experiment area of the Universidade Estadual de Montes Claros (UNIMONTES), in Janaúba, MG, Brazil, from October to November 2014. The experiment area was drip-irrigated daily, and the plants were not treated with pesticides, to allow for natural infestation by $S$. frugiperda.

The pequi fruit peels were chopped, dried in a forced air circulation oven $\left(65^{\circ} \mathrm{C}\right.$ for 72 hours), and ground in an electric grinding mill coupled with a sieve containing $1 \mathrm{~mm}$ openings, to obtain a powder. Prior to use, the powder was stored in a refrigerator at $10^{\circ} \mathrm{C}$ in glass vials $(7 \mathrm{~cm}$ $\times 14 \mathrm{~cm}$ ), which were closed with screw caps and covered with aluminum foil. A base-line extract $(10 \% \mathrm{v} / \mathrm{v})$ was prepared by adding $100 \mathrm{~mL}$ of powder to a $1 \mathrm{~L}$ glass flask, to which about $900 \mathrm{~mL}$ of deionized sterile water was then added. The flask was wrapped with aluminum foil and stored in a refrigerator $\left(10^{\circ} \mathrm{C}\right)$ for 24 hours to allow for the extraction of water-soluble compounds. The solution was then poured through a fine voile fabric. The $10 \%$ extract was then diluted with deionized sterile water to obtain $0.8 \%, 2.5 \%$, and $5 \%$ solutions.

The four concentrations of aqueous extract were sprayed on corn plants 40 and 47 days after germination. Control plants were sprayed with water only. The extract was sprayed on each plant to the point of run-off using a manual sprayer (2 L capacity).

The presence of $S$. frugiperda in the experiment area was suggested by the occurrence of damage to the leaves, which was presumably caused by the fall armyworm. Four evaluations were performed: two after the first spraying of the extract, and two after the second. To score the intensity of damage to the leaves, we used the visual scale proposed by SOUZA et al. (2011):

0 - no damaged leaves;

1 - scraped leaves;
2 - punctured leaves;

3 - cut leaves;

4 - defective whorl;

5 - completely destroyed whorl.

The plants were also monitored for visual symptoms that could indicate phytotoxicity of the pequi extract.

The experiment was conducted in a randomized block design, with five treatments (four pequi extract concentrations and a water control) and five replications. Each plot consisted of five lines of five plants each, with $100 \mathrm{~cm}$ spacing between blocks, totaling 25 plants per treatment. The results were subjected to a variance analysis $(5 \times 4$ factorial design, extract concentration $\times$ evaluation time) and a regression analysis using the statistical software Sisvar ver. 5.3 (FERREIRA, 2010). We also calculated the frequency distribution of the damage scores.

During our study, S. frugiperda was present in the field, damaging the corn plants throughout the period in which the evaluations were carried out (Fig. 1). Damage was observed during the first assessment, which occurred 3 days after the first spraying of the extract, and 43 days after germination. At this time, damage was limited to scores 1 and 2 , and consisted of superficially scraped leaves, indicating the beginning of an insect attack in the control and the $0.8 \%$ and $2.5 \%$ treatments. During subsequent evaluations, it was found that the insect inserted itself into the experiment area and began to cause more extensive damage, destroying the entire whorl of some plants. This study suggests that pequi extract reduced damage caused by the fall armyworm in corn. The results of the second evaluation (6 days after spraying) suggest that the pequi extract was harmful to the fall armyworm. Indeed, according to OLIVEIRA et al. (2007), plant-based products begin to affect the development of the fall armyworm a few days after leaf spraying, usually 7 days after application. Plants treated with $0.8 \%$ extract continued to be damaged even after the second application, although the percentage with completely damaged whorls was lower than that of the control plants (Fig. 1). This indicates that spraying with $0.8 \%$ pequi extract did not fully protect the plants, but reduced damage severity, suggesting that some of the caterpillars may have died. Treatment with $2.5 \%$ and $5 \%$ extract prevented an increase in damage caused by the caterpillars, since the percentages of plants with damage scores of 4 and 5 were much smaller than those observed in the control and $0.8 \%$ treatment group. The first spraying of the $10 \%$ extract prevented the occurrence of damage caused by the fall armyworm, however, the second spraying caused symptoms consistent with phytotoxicity. Therefore, this treatment was not included in the data analysis.

There was a significant interaction between extract concentration and number of days after the first spraying $(\mathrm{F}=3.946$, $\mathrm{p}<0.0005$ ), with respect to average damage score (Fig. 2 and 3). 

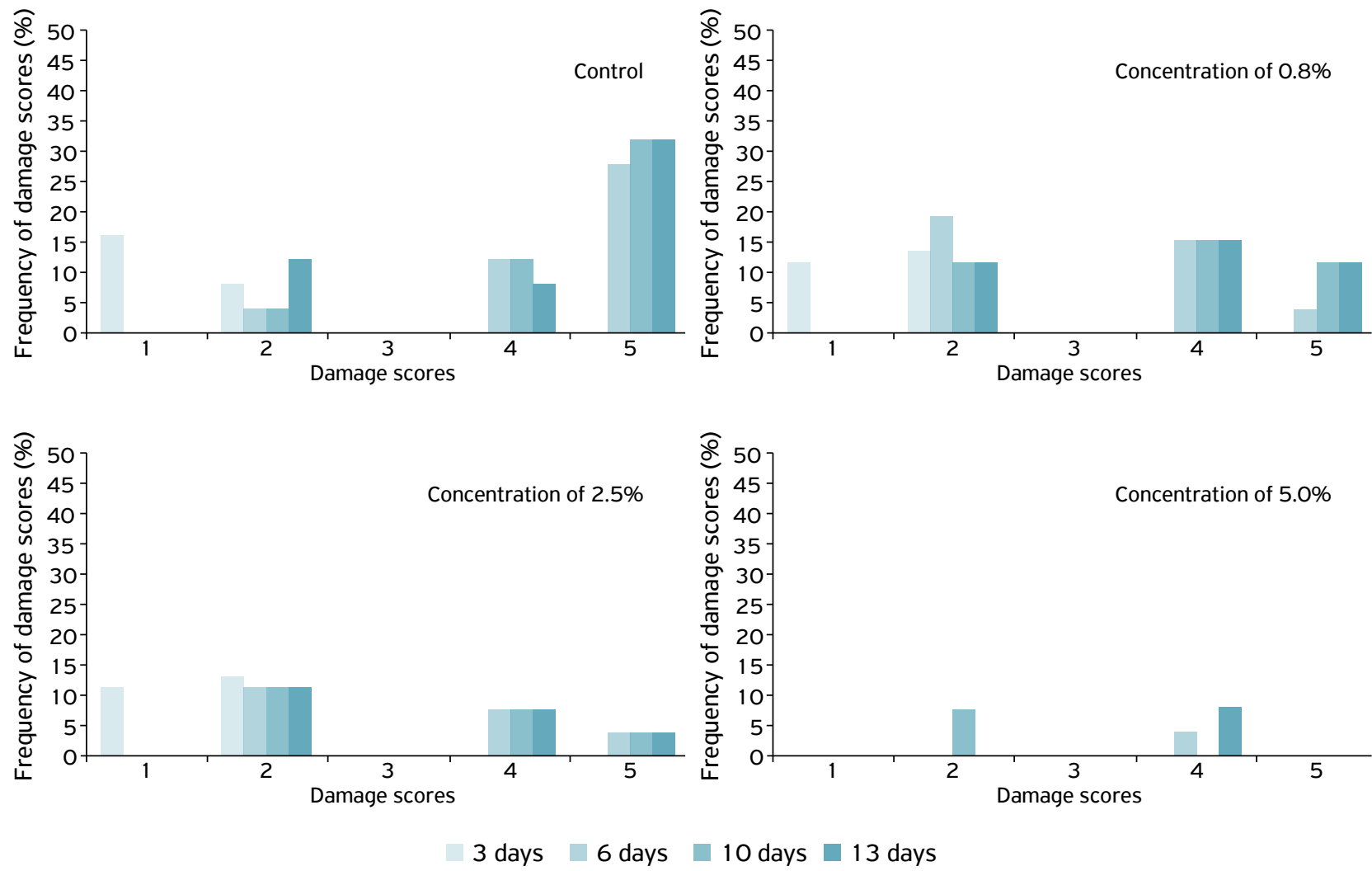

Figure 1. Frequency distribution for the damage scores attributed to Spodoptera frugiperda feeding on corn plants 3, 6, 10, and 13 days after the first spraying with different concentrations of an aqueous extract of pequi (Caryocar brasiliense) fruit peels or water (control).
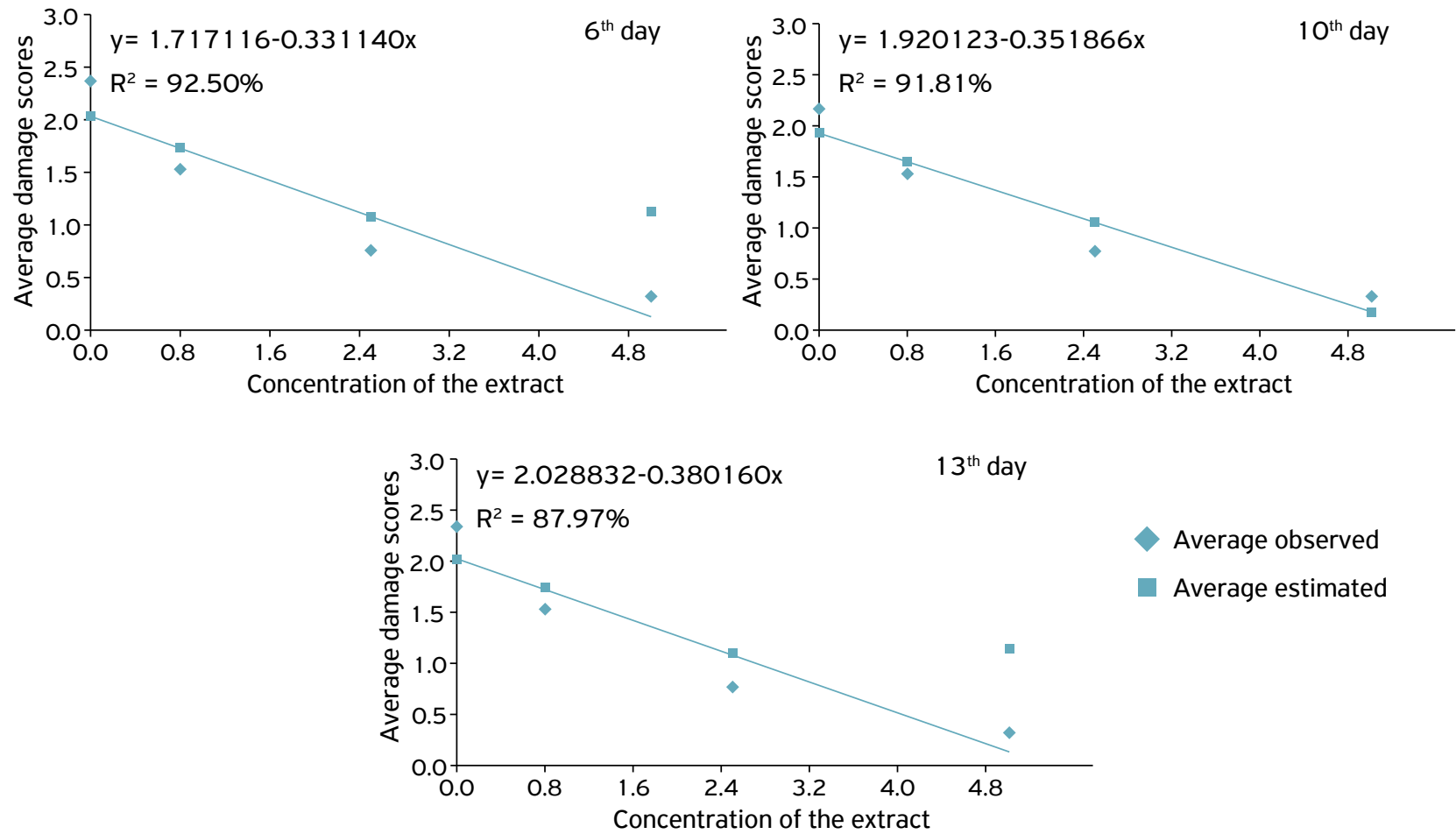

Average observed

Average estimated

Figure 2. Average damage scores attributed to Spodoptera frugiperda feeding on corn plants sprayed with different concentrations of an aqueous extract of pequi (Caryocar brasiliense) fruit peels, separated by number of days after the first spraying. 

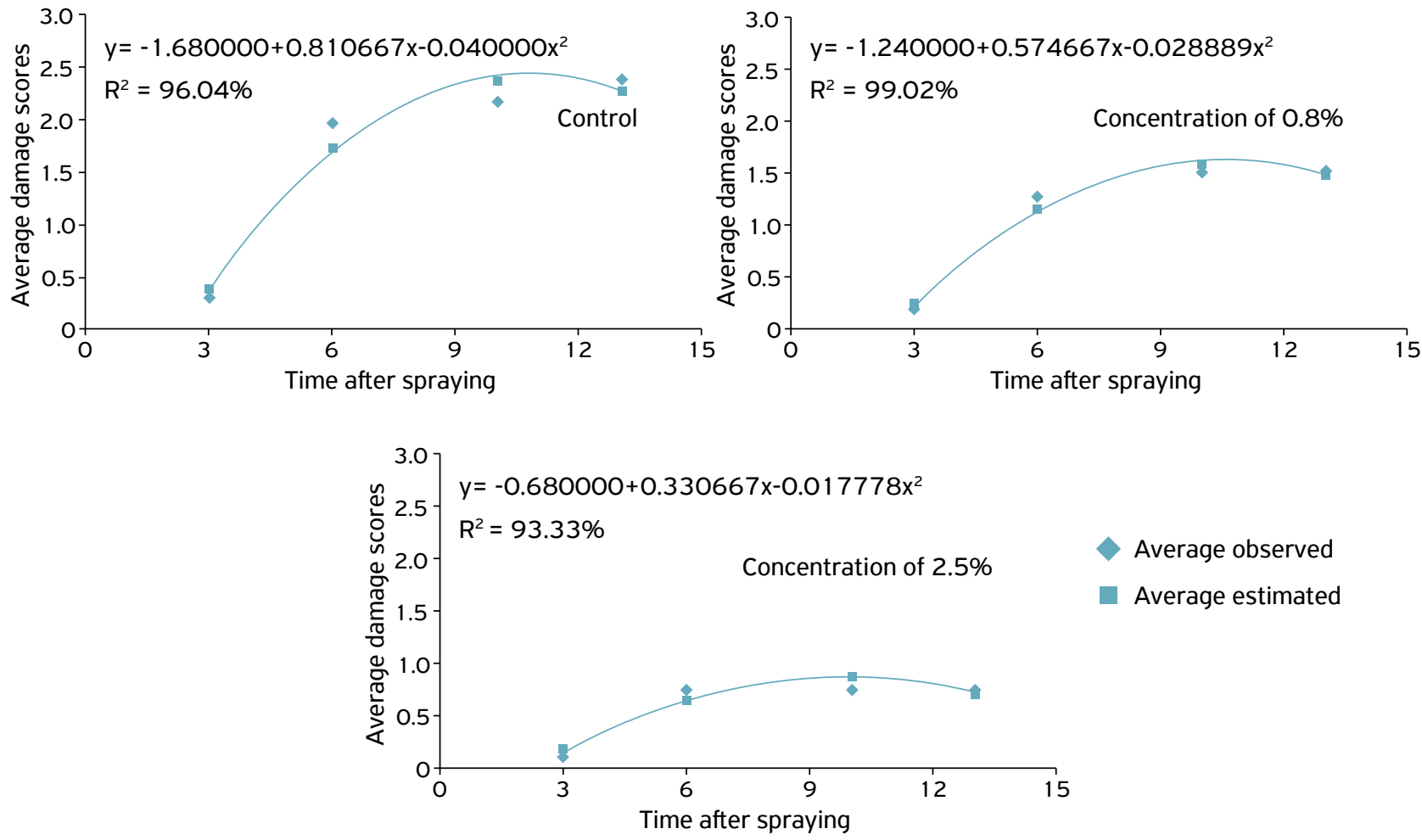

Average observed

Average estimated

Figure 3. Average damage scores attributed to Spodoptera frugiperda feeding on corn plants sprayed with different concentrations of an aqueous extract of pequi (Caryocar brasiliense) fruit peels, separated by extract concentration.

For the evaluations performed 6,10 , and 13 days after the first spraying, the regression analysis indicated that damage scores were inversely proportional to the concentration of pequi extract (Fig. 2).

The analysis of days after the first extract spraying for each extract concentration indicated that there were significant effects for the control, $0.8 \%$ and $2.5 \%$ treatments, but not for the $5 \%$ treatment (Fig. 3). For the control, $0.8 \%$ and $2.5 \%$ treatments, the inflection point of the curve occurred close to 10 days after the first spraying. Furthermore, the highest average damage scores estimated by the models 10 days after spraying were $2.42,1.62$, and 0.82 , respectively, indicating that higher concentrations of extract resulted in lower average damage scores (Fig. 3).

According to MACHADO et al. (2007), the variation in efficiency of botanical extracts for pest control depends on the concentration used and how long the product remains effective. The need for more frequent sprayings of botanical insecticides may be related to the growth of new plant tissue (VIANA et al., 2007), as well as to the degradation of the insecticide when exposed to field conditions (AGUIAR-MENEZES, 2005). In this study, corn plants were sprayed only twice with pequi extracts, yet this botanical insecticide still reduced the damage caused by $S$. frugiperda. The observed reduction of damage caused by fall armyworm may have resulted from the toxic substances in the aqueous extract of pequi peels that interfere with the growth and development of the insects, either through food deterrence or toxicity (SCHOONHOVEN et al., 2005).

The aqueous extract of pequi fruit peels may be more suitable for controlling the early stages of $S$. frugiperda infestations in corn, at a time when the caterpillars have not yet reached the inner-most leaves of the whorl, since caterpillars in this region are less likely to have direct contact with sprayed insecticides. Furthermore, caterpillars in the early instars are usually more susceptible to secondary metabolites of plants, when exposed through direct contact or ingestion during feeding (TRINDADE et al., 2014).

Based on our results, the aqueous extract of pequi fruit peels shows promise for reducing damage caused by $S$. frugiperda to corn plants, providing low-income farmers with an easy, natural, and low-cost means of pest management using locally-sourced materials.

\section{ACKNOWLEDGMENTS}

The authors acknowledge CAPES, FAPEMIG, and CNPq for supporting this research. 

REFERENCES

AGUIAR-MENEZES, E. de L. Inseticidas botânicos: seus princípios ativos, modo de ação e uso agrícola. Seropédica: Embrapa Agrobiologia, 2005. 58 p. (Documentos, 205).

COITINHO, R.L.B. de C.; OLIVEIRA, J.V. de; GONDIM JUNIOR, M.G.C.; CÂMARA, C.A.G. da. Atividade inseticida de óleos vegetais sobre Sitophilus zeamais Mots. (Coleoptera: Curculionidae) em milho armazenado. Caatinga, Mossoró, v.19, n.2, p.176-182, 2006a.

COITINHO, R.L.B. de C.; OLIVEIRA, J.V. de; GONDIM JUNIOR, M.G.C.; CÂMARA, C.A.G. da. Efeito residual de inseticidas naturais no controle de Sitophilus zeamais Mots. em milho armazenado. Caatinga, Mossoró, v.19, n.2, p.183-191, 2006b.

FERREIRA, D.F. Sisvar: Sistema de análise de variância. Versão 5.3. Lavras -MG: UFLA, 2010.

MACHADO, L.A.; SILVA, V.B.; OLIVEIRA, M.M. Uso de extratos vegetais no controle de pragas em horticultura. Arquivos do Instituto Biológico, São Paulo, v.69, n.2, p.103-106, 2007.

OLIVEIRA, M.S.S.; ROEL, A.R.; ARRUDA, E.J.; MARQUES, A.S. Efficiency of extracts of plants in control of fall armyworm in corn Spodoptera frugiperda (J. E. Smith, 1797) (Lepidoptera: Noctuidae). Ciência e Agrotecnologia, Lavras, v.31, n.2, p.326-331, 2007.
RESENDE, G.A.A.; TERRONES, M.G.H.; RESENDE, D.M.L.C. Estudo do potencial alelopático do extrato metanólico de raiz e caule de Caryocar brasiliense Camb. (Pequi). Bioscience Journal, Uberlândia, v.27, n.3, p.460-472, 2011

SCHOONHOVEN, L.M.; LOON, J.J.A.; DICKE, M. Insect-plant biology. 2 ed. New York: Oxford, 2005. 421 p.

SOUZA, C.K.L.; SILVA, A.B.; BESERRA, E.B.; DANTAS, J.P. Controle de Spodoptera frugiperda (J. E. Smith, 1797) e Helicoverpa zea (Boddie, 1850) em plantas de milho tratadas com extratos vegetais em dois intervalos de pulverização. Boletín de Sanidad Vegetal Plagas, Madrid, v.37, n.2, p.45-56, 2011.

TRINDADE, R.C.P.; ARAÚJO-JÚNIOR, J.X.; SANT'ANA, A.E.G.; AQUINO, P.G.V.; SOUSA, R.S.; COSTA, A.P.A.A. Utilização de extratos aquosos de Aspidosperma macrocarpum sobre diferentes estágios de lagartas da traça-das-crucíferas. Ciência Agrícola, Rio Largo-Alagoas, v.12, n. 1, p.21-26, 2014.

VIANA, P.A.; PRATES, H.T.; RIBEIRO, P.E.A. Efeito de extratos de nim e de métodos de aplicação sobre o dano foliar e o desenvolvimento da lagarta-do-cartucho, Spodoptera frugiperda, em milho. Revista Brasileira de Milho e Sorgo, Sete Lagoas, v.6, n. 1, p. 17-25, 2007 